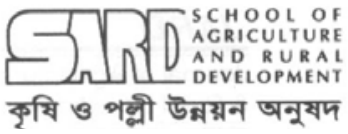

J ARD

Journal of Agriculture

\& Rural Development

\title{
Preparation of Mixed Oil Pickling Using Capsicum, Green Chilli and Carrot
}

\author{
M. M. MOLla ${ }^{1 *}$, T.A.A.NASRIN ${ }^{2}$ AND M. AlAMgir HosSAIN ${ }^{3}$ \\ ${ }^{1,2 \& 3}$ Post Harvest Technology Section, HRC, Bangladesh Agricultural Research Institute, Gazipur, Bangladesh
}

\begin{abstract}
The study was conducted at Post Harvest Technology Section, HRC, BARI, Gazipur during 20062007 to find out a suitable formulation for preparation of mixed oil pickling using capsicum, green chilli and carrot. Three types of mixed oil pickling formulation viz. mature capsicum + green chilli + paste carrots $\left(T_{1}\right)$, ripen capsicum + green chilli + paste carrots $\left(T_{2}\right)$ and immature capsicum + green chilli + paste carrots $\left(T_{3}\right)$ were prepared using varying proportions of capsicum, green chilli and paste carrots. The prepared mixed oil pickles were packed in glass bottle with lug cap. The fresh ingredients and stored pickles were analyzed for nutritional composition. Among the formulation mature capsicum + green chilli + paste carrots $\left(T_{1}\right)$ performed the best according to the taste testing panel using sensory attributes comprised colour, flavour, consistency and overall acceptability along with 9-point hedonic scale. Recorded data were analyzed statistically. After 120 days storage periods the nutritional content found little deviation from the fresh ingredients of mentioned formulation. Therefore, it is recommended for prepare mixed oil pickling mature capsicum + green chilli + paste carrots $\left(T_{1}\right)$ which may be stored up to 120 days.
\end{abstract}

Key words: Pickling, Vitamin-C, Pro-vitamin-A and storage studies.

\section{INTRODUCTION}

The process of food preservation in common salt or in vinegar or in both is called pickling. Pickling with the help of vinegar and oils has been in practice from time immemorial in this country. In modern days, pickles of different fruits and vegetables are prepared with the mixture of salt, oil, vinegar and spices etc. In pickles, oil acts as preservative (Shahjahan et.al, 2005). Green chilli is used as spice in cooking food, raw in salad and pickle (Pruthi, 1976). Chillies are widely used throughout the tropics and are major ingredients of curry powder in the culinary preparations (Bose $T K$ and Som M G, 1986). The green chilli is rich in vitamin-C and pro- vitamin-A which is of immense pharmaceuticals need (Purseglove, 1977). In the year 2003-2004, area under chilli cultivation was 420 acres of land with a production of 137 metric tons (Anon, 2004). Carrot is another important vegetable which is rich in pro-vitamin-A and is good for preventing heart attack and cancer. An infusion of carrot has long been used as a folk medicine for thread worms. Carrot increases the quantity of urine and helps the elimination of uric acid. Addition of large amount of carrot to the diet has a favourable effect on the nitrogen balance (Bose T K and Som M G, 1986). Chopra, 1933; Kirtikar and Basu, 1935, reported that carrots are useful in disease of the kidney and in dropsy. Capsicum (sweet peppers, green or red) may be eaten cooked or raw, sliced in salads (Bose T K and Som M G, 1986). Mild or sweet peppers are also used for pickling in brine, backing

"Corresponding author: Scientific Officer, BARI, Joydebpur, Gazipur; Cell: 01712231121; E-mail: mainuddin.hrc@bari.gov.bd

(C) 2006 School of Agriculture and Rural Development, Bangladesh Open University, All rights reserved. 


\section{M.M. Molla et al.}

and stuffing. Diced green or red sweet peppers are sometimes mixed with sweet corn or other vegetables (Shoemaker and Teskey, 1955). Capsicum is considered by some to be a stimulant for sluggish digestive systems, effective in curing sore throats, malaria, colic and alcoholism (Farrell, 1990). But there is no processed product being formulated by mixed oil pickling from these commodities. If proper processing technology can be developed it is possible to utilize the capsicum, carrot and green chilli properly. With the above views in consideration, this study was taken to prepare mixed oil pickles from capsicum and green chilli and to investigate the acceptability of the products.

\section{MATERIALS AND METHODS}

The experiment was conducted in the laboratory of Post-harvest Technology Section, Horticulture Research Centre (HRC) of the Bangladesh Agricultural Research Institute (BARI), Joydebpur, Gazipur. Three stage of capsicum i.e. immature (green), mature (pale green with light yellow color at the bottom of the capsicum) and ripen (fully colored), carrots, green chilli, acetic acid, salt and other spices were used in the experiment. Carrot was procured from the local market. Capsicum was collected from the field. The quantity of ingredients for mixed oil pickling was given on Table 1. A schematic diagram of mixed oil pickling was as follows.

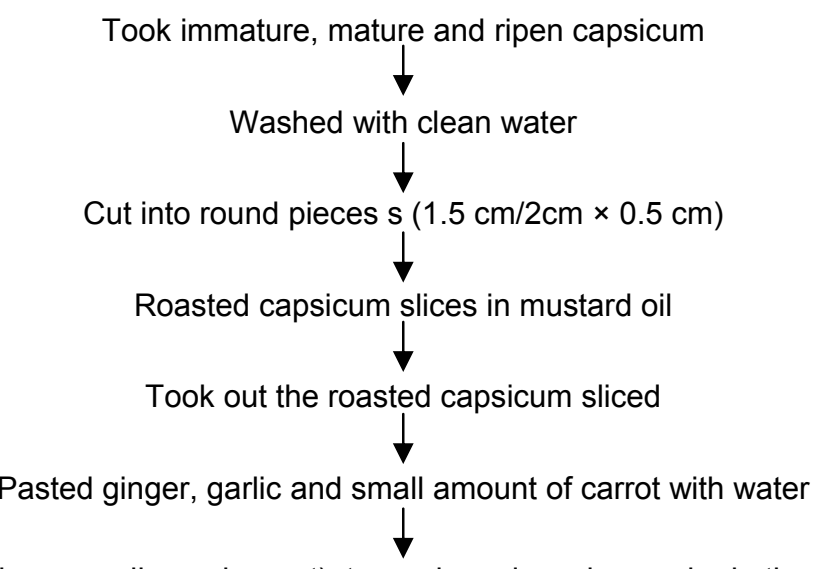

Added the pasted (ginger, garlic, and carrot), turmeric and cumin powder in the remaining oil on the pan and roasted

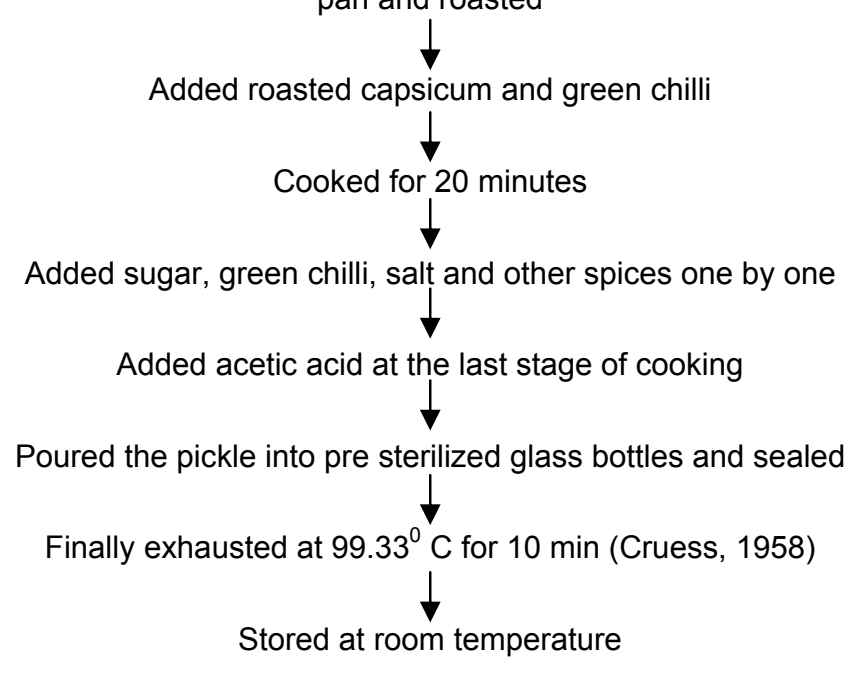




\section{Formulation different oil pickling}

Three types of oil pickling were formulated as follows:

Mature capsicum + green chilli + paste carrots $\left(T_{1}\right)$

Ripen capsicum + green chilli + paste carrots $\left(T_{2}\right)$

Immature capsicum + green chilli + paste carrots $\left(T_{3}\right)$

Table 1. Recipe for preparation of mixed oil pickling

\begin{tabular}{lclc}
\hline \multicolumn{1}{c}{ Name of ingredients } & Quantity & Name of ingredients & Quantity \\
\hline Capsicum & $1 \mathrm{Kg}$ & Mustard powder & $30 \mathrm{~g}$ \\
Garlic & $40 \mathrm{~g}$ & Fenugreek powder & $5 \mathrm{~g}$. \\
Ginger & $80 \mathrm{~g}$ & Salt & $60 \mathrm{~g}$. \\
Green chilli (Fermentation) & $120 \mathrm{~g}$ & Cumin powder & $4 \mathrm{~g}$. \\
Naga morich & $20 \mathrm{~g}$ & Mustard oil & $500 \mathrm{ml}$. \\
Carrot & $150 \mathrm{~g}$ & Acetic Acid & $15 \mathrm{ml}$. \\
Turmeric powder & $10 \mathrm{~g}$ & Sugar & $120 \mathrm{~g}$ \\
\hline
\end{tabular}

Table 2. Rating score for colour, flavour, consistency and overall acceptability of different treatments

\begin{tabular}{|c|c|c|c|c|c|c|c|c|c|c|c|c|c|c|c|}
\hline \multirow{2}{*}{$\begin{array}{l}\text { No. of } \\
\text { taster }\end{array}$} & \multicolumn{3}{|c|}{ colour } & \multicolumn{3}{|c|}{$\begin{array}{l}\text { Flavour of } \\
\text { green chilli }\end{array}$} & \multicolumn{3}{|c|}{$\begin{array}{l}\text { Flavour of } \\
\text { capsicum }\end{array}$} & \multicolumn{3}{|c|}{ Consistency } & \multicolumn{3}{|c|}{$\begin{array}{c}\text { Overall } \\
\text { acceptability }\end{array}$} \\
\hline & $\mathrm{T}_{1}$ & $\mathrm{~T}_{2}$ & $\mathrm{~T}_{3}$ & $\mathrm{~T}_{1}$ & $\mathrm{~T}_{2}$ & $\mathrm{~T}_{3}$ & $\mathrm{~T}_{1}$ & $\mathrm{~T}_{2}$ & T3 & $\mathrm{T}_{1}$ & $\mathrm{~T}_{2}$ & T3 & $\mathrm{T}_{1}$ & $\mathrm{~T}_{2}$ & T3 \\
\hline 1 & 9 & 6 & 3 & 9 & 7 & 3 & 8 & 3 & 1.5 & 9 & 6 & 3 & 9 & 6 & 3 \\
\hline 2 & 9 & 5 & 3 & 7 & 3 & 1.5 & 7 & 4 & 2 & 8 & 6 & 3 & 10 & 7 & 4 \\
\hline 3 & 7 & 3 & 2 & 8 & 4 & 1.5 & 6 & 3 & 1.5 & 7 & 5 & 2 & 6 & 5 & 2 \\
\hline 4 & 8 & 6 & 2 & 8 & 3 & 1.5 & 8 & 3 & 1.5 & 6 & 3 & 2 & 8 & 5 & 3 \\
\hline 5 & 9 & 5 & 2 & 8 & 7 & 3 & 8 & 6 & 3 & 10 & 6 & 3 & 8 & 5 & 2 \\
\hline 6 & 9 & 6 & 3 & 8 & 6 & 3 & 10 & 6 & 3 & 8 & 5 & 2 & 9 & 6 & 4 \\
\hline 7 & 8 & 4 & 2 & 7 & 5 & 2 & 8 & 5 & 2 & 8 & 5 & 2 & 8 & 5 & 2 \\
\hline 8 & 6 & 3 & 1.5 & 7 & 3 & 2 & 7 & 4 & 2 & 8 & 6 & 3 & 7 & 4 & 2 \\
\hline 9 & 8 & 3 & 1.5 & 7 & 3 & 1.5 & 6 & 3 & 1.5 & 7 & 3 & 2 & 8 & 5 & 3 \\
\hline 10 & 8 & 5 & 2 & 7 & 4 & 2 & 8 & 5 & 2 & 8 & 4 & 2 & 9 & 6 & 3 \\
\hline Total & 81 & 46 & 22 & 77 & 45 & 20 & 75 & 42 & 20 & 79 & 49 & 24 & 82 & 54 & 28 \\
\hline Mean & 8.1 & 4.6 & 2.2 & 7.7 & 4.5 & 2.0 & 7.5 & 4.2 & 2.0 & 7.9 & 4.9 & 2.4 & 8.2 & 5.4 & 2.8 \\
\hline
\end{tabular}

Mature capsicum + green chilli + paste carrots $\left(T_{1}\right)$

Ripen capsicum + green chilli + paste carrots $\left(T_{2}\right)$

Immature capsicum + green chilli + paste carrots $\left(T_{3}\right)$

Table 3. Mean score for colour, flavour, consistency and overall acceptability of different treatments

\begin{tabular}{lccccc}
\hline \multirow{2}{*}{ Treatments } & \multicolumn{4}{c}{ Sensory Attributes } \\
\cline { 2 - 6 } & Color & $\begin{array}{c}\text { Flavor of } \\
\text { green chilli }\end{array}$ & $\begin{array}{c}\text { Flavor of } \\
\text { capsicum }\end{array}$ & Consistency & Overall acceptability \\
\hline $\mathrm{T}_{1}$ & $8.10^{\mathrm{a}}$ & $7.70^{\mathrm{a}}$ & $7.50^{\mathrm{a}}$ & $7.90^{\mathrm{a}}$ & $8.20^{\mathrm{a}}$ \\
$\mathrm{T}_{2}$ & $4.60^{\mathrm{b}}$ & $4.50^{\mathrm{b}}$ & $4.20^{\mathrm{b}}$ & $4.90^{\mathrm{b}}$ & $5.40^{\mathrm{b}}$ \\
$\mathrm{T}_{3}$ & $2.50^{\mathrm{c}}$ & $2.30^{\mathrm{c}}$ & $2.10^{\mathrm{c}}$ & $2.60^{\mathrm{c}}$ & $3.30^{\mathrm{c}}$ \\
\hline $\mathrm{cv}(\%)$ & 9.46 & 13.16 & 11.47 & 9.02 & 6.58 \\
\hline
\end{tabular}

Mature capsicum + green chilli + paste carrots $\left(T_{1}\right)$

Ripen capsicum + green chilli + paste carrots $\left(T_{2}\right)$

Immature capsicum + green chilli + paste carrots $\left(T_{3}\right)$

Analysis of mixed oil pickle: The mixed oil pickles were analyzed for its vitamin-C and provitamin-A was determined according to Ranganna (1991).

Sensory evaluation of mixed oil pickling: Sensory evaluations of all the formulated mixed oil pickling were done by taste testing panel. The taste testing panel was consisted of ten judges. They were asked to evaluate colour, flavour of green chilli and capsicum, consistency and over all 
acceptability of the product by a scoring rate on a 9- point hedonic scale. $9=$ Like extremely, $8=$ Like very much, 7=Like moderately, 6=Like slightly, 5=Neither like nor dislike, 4=Dislike slightly, $3=$ Dislike moderately, 2=Dislike very much and 1=Dislike extremely. The different preferences as indicated by scores were evaluated by statistical methods. The analysis of variance method was used for this evaluation. The difference was quantified by Duncan's Multiple Range Test. The procedures of MSTAT were used for statistical analysis.

Storage studies: Prepared mixed oil pickling was stored at room temperature $\left(28-32^{\circ} \mathrm{C}\right)$. The different parameters for storage studies of mixed oil pickling were observed at a 30 days of interval.

\section{RESULTS}

A highly significant variation was observed among the treatments. It was revealed that formulation mature capsicum + green chilli + paste carrots $\left(T_{1}\right)$ showed better performance than formulation ripen capsicum + green chilli + paste carrots $\left(T_{2}\right)$ and immature capsicum + green chilli + paste carrots $\left(T_{3}\right)$.

Vitamin-C: Vitamin-C content of fresh carrot, capsicum, and green chilli were found 3.0, 175.0 and $110.0 \mathrm{mg} / 100 \mathrm{~g}$ on the day of preparation (O day) (Table 4). After $30,60,90$ and 120 days of storage periods the vitamin-c ranges were decreased and found 2.94-2.65, 170-135 and 110-50 $\mathrm{mg} / 100 \mathrm{~g}$ respectively (Table 5 ).

Table 4. Vitamin-C and Pro-vitamin-A of fresh carrot, capsicum and green chilli

\begin{tabular}{lcc}
\hline Name of ingredients & Vitamin-C (mg/100gm) & Pro-vitamin -A(I.U/100g) \\
\hline Carrot & 3.00 & 3000.00 \\
Capsicum & 175.00 & 545.00 \\
Green chilli & 110.00 & 53.00 \\
\hline
\end{tabular}

Table 5. Analysis of vitamin-C and pro-vitamin-A of fresh carrot, capsicum and green chilli at different storage periods

\begin{tabular}{lcccccccc}
\hline Name of & \multicolumn{3}{c}{ Vitamin-C (mg/100gm) } & \multicolumn{3}{c}{ Pro-vitamin -A (I.U/100g) } \\
\cline { 2 - 8 } ingredients & 30 days & 60 days & 90 days & 120 days & 30 days & 60 days & 90 days & 120 days \\
\hline Carrot & 2.94 & 2.89 & 2.84 & 2.65 & 2850.00 & 2740.00 & 2600.00 & 2200.00 \\
Capsicum & 170.00 & 165.00 & 150.00 & 135.00 & 545.00 & 540.00 & 480.00 & 460.00 \\
Green chilli & 108.40 & 91.00 & 73.00 & 50.00 & 45.21 & 39.40 & 35.43 & 21.0 \\
\hline
\end{tabular}

Pro -Vitamin-A: Pro-vitamin-A of fresh carrot, capsicum and green chilli were found 3000.0, 535.0 and $53.0 \mathrm{I} . \mathrm{U} / 100 \mathrm{~g}$ respectively on the day of preparation (O day) (Table 4). After 30, 60, 90 and 120 days of storage periods, the pro-vitamin-A ranges were decreased and found 2850.0-2200.0, 535.0-460.0 and 53.0-21.0 I.U/100g respectively (Table 5).

Sensory evaluation: Preparation of all mixed oil pickling were subjected to sensory evaluation for color, flavor, consistency and overall acceptability. Three formulations were evaluated by randomly selected judges (Table-2). Initial test showed that formulation mature capsicum, green chilli and paste carrots $\left(T_{1}\right)$ was better than ripen capsicum, green chilli and paste carrots $\left(T_{2}\right)$ and immature capsicum, green chilli and paste carrots $\left(T_{3}\right)$.

Storage studies: Prepared mixed oil pickling was stored at room temperature (28-32 ${ }^{0}$. During the storage period of 120 days, colour, flavour and gas formation were observed. There was no change in color and flavour up to120 days of storage periods. Gas formation was slightly changed in the formulation immature capsicum + green chilli + paste carrots $\left(T_{3}\right)$ at 120 days storage period.

\section{DISCUSSION}

The decreased vitamin- $C$ might be due to its oxidation during the long concentration steps in room temperature. The results were similar to El.Ashwah et.al (1980).

The decreased pro-vitamin-A might be due to increased storage temperature. The researcher Rygg (1949) mentioned that increased storage temperature over the range $2-24^{\circ} \mathrm{C}$ had little effect on 
changes in carotene content. Miller et.al. , (1949) also identified the loss of carotene after 4 month storage period. Elkins(1979) found that little loss of - $\beta$ carotene from green beans, peaches and sweet potatoes, which support the present research findings.

The slightly changed of gas formation might be due to its immaturity and oxidation during the long concentration steps. Similar observation was made by El.Ashwah et.al (1980).

The mean score for colour, flavour, consistency and overall acceptability of three formulations were shown in Table 3. A two-way analysis of variance was conducted for all the attributes. The DMRT test revealed that for all attributes formulation mature capsicum + green chilli + paste carrots $\left(T_{1}\right)$ was most preferred and significantly better than formulation ripen capsicum + green chilli + paste carrots $\left(T_{2}\right)$ and immature capsicum + green chilli + paste carrots $\left(T_{3}\right)$. But the formulation ripen capsicum + green chilli + paste carrots $\left(T_{2}\right)$ and immature capsicum + green chilli + paste carrots $\left(T_{3}\right)$ were not significantly different in all attributes. This indicates that the panelists equally accepted the formulation mature capsicum + green chilli + paste carrots $\left(T_{1}\right)$.

\section{CONCLUSION}

The study indicates that formulation mature capsicum + green chilli + paste carrots $\left(T_{1}\right)$ showed best results compared to other formulations. Carrot, capsicum and green chilli can be easily processed into mixed oil pickling in rural areas where modern facilities of processing do not exist. The developed process of preparation of mixed oil pickling of these perishable crops can be acceptable also for home processes and food industries. At the grower's level, establishment of small processing centers can utilize the commodities in production season to make the products for selling during off seasons to bring economic benefits to them.

\section{ACKNOWLEDGEMENT}

The author feels proud to express his heartiest sense of gratitude, authentic thankfulness, immense regards, sincere appreciation and indebtedness to his respect and honourable M. Harun-ur-Rashid, Director General, BARI, Gazipur for his endless encouragement, ever well wishing suggestions, scholastic advice and providing necessary facilities to conduct study in the Post harvest Technology Section, HRC, BARI, Gazipur.

The author finds it a great pleasure to express his gratitude to Mr. Sreekanta Sheel, consultant FAO, Ranjit Shen, Scientific Officer, Soil Science Division and Engg. Md. Abdur Razzaq Akanda, SSO, IWM, Gazipur for their co-operation, encouraging suggestions and valuable advice during the period of this study.

The author is also grateful to M. Nazimuddin, Scientific Officer, Olericulture Division, HRC, BARI, Gazipur for his constant inspiration during the period of this study.

\section{LITERATURE CITED}

Anon, 2004. Bangladesh Bureau of statistics. Statistical year book of Bangladesh, Dhaka; Statistics Division, Ministry of planning, Government of Bangladesh. 143 pp.

Anon, 2004. Year Book of Agricultural Statistics of Bangladesh. Bangladesh Bureau of Statistics. Statistics Division, Ministry of Planning, Government of the Peoples Republic of Bangladesh, Dhaka. 72 pp.

Bose, T. K. and Som, M. G. 1986. Vegetables crops in India. Department of Horticulture. Bidhan Chandra Krishi Viswavidyalaya, Kalyani 741235 India. Naya Prokash, Calcutta-Six. 352-409 pp.

Chopra, R .N. 1933. Indigenous drugs of India, The art press, Calcutta.

Cruess, W. V. 1958. Commercial fruit and vegetables products; Fourth edition, MC-Graw Hill book Co.Inc.Newyork. 113-115 pp.

El. Ashwah F. A.; Abd-El-Baki. N. M.; El. Samahy, S. K.; El. Fedul, M. G. 1980. Effect of storage on the characteristics of the concentrated orange and lime beverages. Agricultural Research review 58(3). 275288 (1980 pub. 1982). Hort.Res. Inst. Agric. Res. Centre. min. of . Agric. Cairo. Egypt. 
M.M. Molla et al.

Elkins. E. R. 1979. Nutritent content of raw and canned green beans, peaches and sweet potatoes, Fd. Technol. Chicago 33, 66-70.

Farrell, K. T. 1990. Spices, Condiments and Seasonings. $2^{\text {nd }}$ edn. Van Nostrand Reinhold. New York, USA. 414pp.

Kirtikar, K. R. and Basu, B. D. 1935. Indian Medicinal Plants (Lolit Mohan Basu), Allahabad.

Miller, J. C., Melampy, R. M., Mikell, J. J. and Hernandez, T. P. 1949. Effect of storage on the carotene content of fourteen varieties of sweet potatoes proc. Am.Soc. Hort-Sci 54, 399-402.

Pruthi, J. S. 1976. Spices and Condiments. National Book Trust, New Delhi, India.269 pp.

Purse glove, J. W. 1977. Tropical crops Dicotyledons I and $\Pi$, Longman, London, pp.524-5.

Ranganna, S. 1991. Hand Book of Analysis and Quality Control for Fruit and Vegetable Products. Tata Mc Graw-Hill Publishing Company Ltd. New Delhi. India. 1112 pp.

Rygg, G. L. 1949. Changes in carotenoid content of harvested carrots, Proc. Am. Soc. Hort. Sci . 54, 307-310.

Shahjahan, M., Miaruddin, M. and Rahman, M. M. 2005. Pickling and fermentation of fruits and vegetables [In: Proceedings of international workshop on agro processing techniques of fruits and vegetables for income generation]. Bangladesh Agricultural Research Institute, Joydebpur, Gazipur.

Shoemaker, J. S. and Teskey, B. J. E. 1955. Practical Horticulture, John Wiley and Sons, Inc,Newyork. 